(RESEARCH ARTICLE)

\title{
Effects of paper wasp (Polistes flavus) venom toxins on lactic dehydrogenase (LDH) and acetyl cholinesterase (AChE) activity in blood serum, liver and muscles of albino mice
}

\author{
Prajapati Krishna Kumar and Upadhyay Ravi Kant * \\ Immuno-Biological laboratory, Department of Zoology,Deen Dayal Upadhyaya Gorakhpur University, Gorakhpur 273009. \\ U.P. India.
}

Publication history: Received on 10 February 2020; revised on 28 February 2020; accepted on 04 March 2020

Article DOI: https://doi.org/10.30574/wjarr.2020.6.1.0039

\begin{abstract}
In the present investigation, in vivo effects of wasp toxin were evaluated on lactic dehydrogenase (LDH) and acetyl cholinesterase (AChE) enzyme activity in serum, liver and gastrocnemius muscles of albino mice. A significant elevation was observed in LDH activity in serum, liver and muscles, while the activity of AChE was decreased in serum, liver and gastrocnemius muscles of albino mice after injected the sub lethal dose of Polistes flavus venom. Increase in the activity of LDH shows liver damage, massive disintegration and necrosis of hepatic cells and leakage of the enzyme into the circulation. High LDH level causes intense stress and hypertension and did a significant increase in the rate of oxidation in animals. Therefore, elevation in LDH level increases the glucose catabolism for energy production especially in anaerobic condition. Besides this, increased level of LDH in muscle and liver cells shows insufficient oxygen supply. In experimental animals accumulation of acetylcholine may lead to prolonged activation of acetylcholine receptors and a permanent stimulation of nerves and muscle cells resulting in muscular paralysis and finally imposed death in experimental animals. Contrary to this, in vitro study of wasp venom toxins directly affected the lactic dehydrogenase activity while the venom toxin of the Polistes flavus not directly affects the acetyl cholinesterase in the serum of the albino mice.
\end{abstract}

Keywords:Polistes flavus; Lactic dehydrogenase; Acetyl cholinesterase; Disintegration and Necrosis.

\section{Introduction}

The paper wasps Polistes flavus are very common species of order- hymenoptera in India and southeastern countries such as Asia, China, Nepal, Bangladesh, Pakistan, Sri-Lanka etc. Wasp belongs to the class- Insecta the second largest class of Arthropod. The wasps are poisonous insects which frequently sting free dwellers, passerby in rural and urban areas. This is a most significant health problem for villages. Wasps inject their toxins into the body of mammals mainly man and his pets. In general stinging hymenopterans are active participants in social defense that have greatly influenced the relationship. They use stinging for territorial defense mainly operated against predators. This is highly adaptive evolutionary mechanism in hymenopterans as they make lethal attack by envenomation in large number [1]. Venom stinging is a strong component that has been developed due to selection pressure during long evolution which is used to make territorial defense by insects as stings are highly of painful and toxic and lethal for intruder. In turn, they have influenced hunting behavior and learning in at least higher primates [2].

Hymenoptera venoms are constituted by a complex mixture of chemically or pharmacologically bioactive agents such as phospholipase, hyaluronidase and mastoparans. Venoms can also contain substances that are able to inhibit and/or diminish the genotoxic or mutagenic action of other compounds that are capable of promoting damages in the genetic material [3]. Wasp venom is a mixture of several biologically active components which induce allergic and inflammatory

* Corresponding author: Upadhyay Ravi Kant E-mail address: rkupadhya@yahoo.com 
toxic reaction in the body of victims after envenomation and alters the activity of the cellular enzymes and altered the normal activity of enzymatic reaction in the body of animals. The venom of the wasp shows multiple biological effects such as swelling in skin, inflammation, rhabdomylysis, paralysis and neurotoxic effects. In contrast, few people show allergy to insect venom, display severe local reactions, systemic symptoms including anaphylactic shock [4] and generates high creatinine levels, shocks, oliguria, and anemia and even causes death [5]. Venom toxins of Polybia paulista showed genotoxic and mutagenic effects and polyamine toxin of wasp is potent open-channel blockers of ionotropic glutamate (IGlu) receptors. These toxins act as voltages dependent channel blockers of $\mathrm{Ca}^{++}$permeable AMPARs [6]. Wasp venom components also affects cholinergic signaling plays important role in regulating the growth and regeneration of axons in the nervous system $[7,8]$.

Venom toxin of Philanthus triangulum (digger wasp), induces paralysis and central as well as a peripheral effects of a pre-synaptic as well as a post-synaptic neurons. The pre-synaptic block is the venom probably caused by an inhibition of the re-uptake of the transmitter in pre-synaptic and block of the skeletal neuromuscular transmission in postsynaptic neurons. The venom contains at least four active toxins called alpha, beta, gamma and delta-philanthotoxin ( $\alpha$ , $\beta-, \gamma$ - and d-PTX). Delta-PTX being the most active toxin in blocking glutamate evoked post-synaptic depolarization. Insect toxins act upon junctional as well as on the extra-junctional, muscles fibers membranes and block delta-PTX ion channels in a dose-dependent manner. Once this channel has been blocked muscle functions loosen[9].

The venom of African wasp (solitary wasp) Philanthus triangulum contains two different cholinergic factors, a competitive and a non-competitive antagonist of the nicotinic receptor of the rectus abdominus muscle of frog Xenopus laevis. The venom of the wasp Habrobracon hebetor pre-synaptically blocks excitatory but not inhibitory neuromuscular transmission at locust skeletal muscle. Like the natural toxin, synthetic delta-philanthotoxin, (PTX4.3.3) acts as a reversible post-synaptic open ion-channel blocker of the glutamatergic neuromuscular system of the locust. It also inhibits the high-affinity to re-uptake of glutamate in the nerve endings and glial cells [10]. The venom also irreversibly blocks the nicotinic synaptic transmission from the cercal nerve to a giant interneuron in the sixth abdominal ganglion and synthetic Thr-bradykinin causes irreversible pre-synaptic activation-induced block of transmission in the insect CNS of the cockroach Periplaneta americana [11].

Acetyl cholinesterase (AChE) is involved in the termination of the impulse transamination in the body tissues of animals by rapid hydrolysis of the nerve transmitter's acetylcholine. It also remains involve in numerous cholinergic pathways in the central nervous system and peripheral nervous systems. The AChE inactivation induced by various inhibitors leads to acetyl choline accumulation, hyper stimulation of the nicotinic and muscarinic receptors and disruption of neurotransmissions [12]. Wasp Ampulex compressa venom induces a transient paralysis of the front legs in cockroach. Venom evokes picrotoxin-sensitive chloride currents in cockroach central neurons, consistent with a GABAergic action [13]. It also impose central synaptic block to induce transient effect that result in paralysis of its host [14]. In present research investigation effects of venoms toxins were established in LDH and AchE activity in blood serum, liver and muscles of albino mice.

\section{Material and methods}

\subsection{Collection of paper wasp}

The living paper wasp Polistes flavus also called yellow wasp due to its coat color were collected from different regions of Gorakhpur city. The collected wasps were immobilized by quick freezing at $-20^{\circ} \mathrm{C}$. The venom glands were taken out by cutting the last two segment of abdominal regions of wasps. These were homogenized in phosphate buffer saline (50 $\mathrm{mM}, \mathrm{pH}$ 6.9) with the help of power homogenizer. The homogenate was centrifuged at $10000 \mathrm{rpm}$ at $4^{\circ} \mathrm{C}$ for 10 minutes and the supernatant was used as crude venom. The crude venom was lyophilized at desire concentration and lyophilized venom was used as pure venom of paper wasp. 

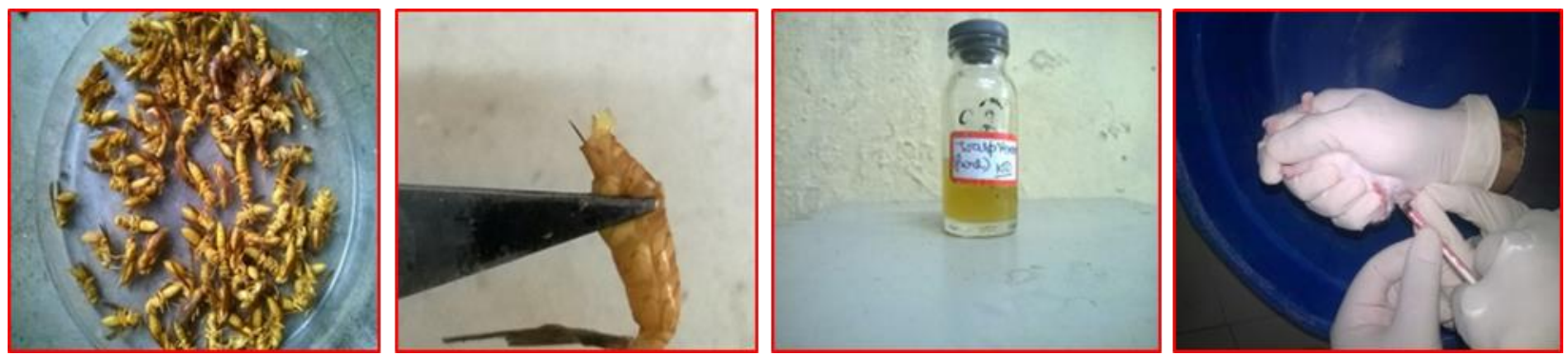

Figure 1 Collection of paper wasp, isolation of venom toxin and inject the venom toxin in albino mice for activity testing of LDH and AChE in vivo.

\subsection{Determination of molecular weight and lethality of paper wasp Polistes flavus venom toxins}

Range of molecular weight of different proteins/toxins in the purified wasp venom was determined by running the proteins of known molecular weight through Sepharose CL-6B gel column chromatography at the $1 \mathrm{ml} / \mathrm{minute}$ flow rate. A calibration curve was drawn between Ve/Vo log $\mathrm{M}$ and with the help of calibration curve range of molecular weight of different protein in the purified paper wasp Polistes flavus venom was determined [15].

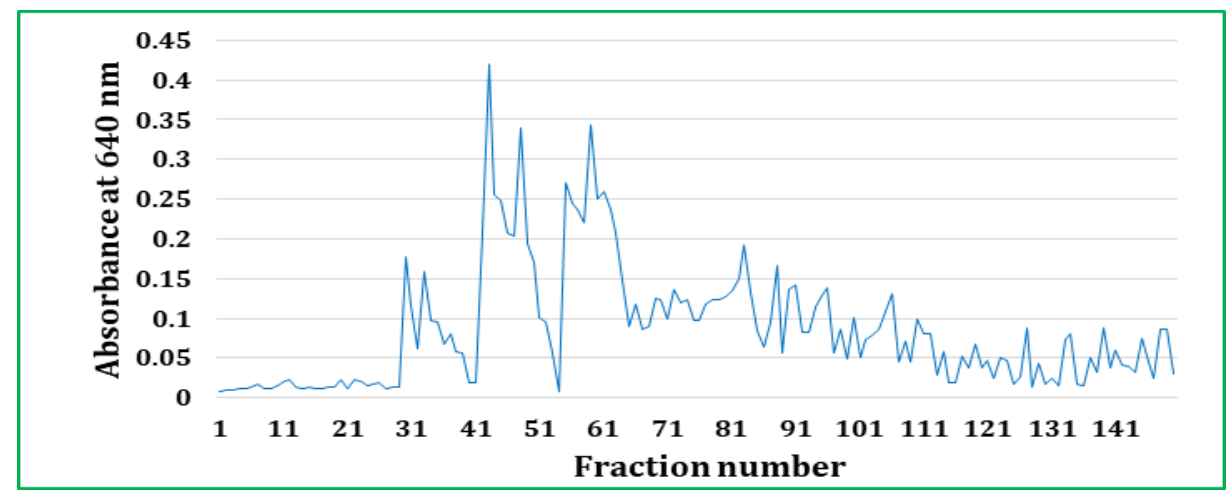

Figure 2 Elution pattern of phosphate buffer ( $50 \mathrm{mM}$, pH 6.9) extractable venom proteins of paper wasp Polistes flavus chromatographed on Sepharose CL-6B column. Absorbance was taken at $640 \mathrm{~nm}$.

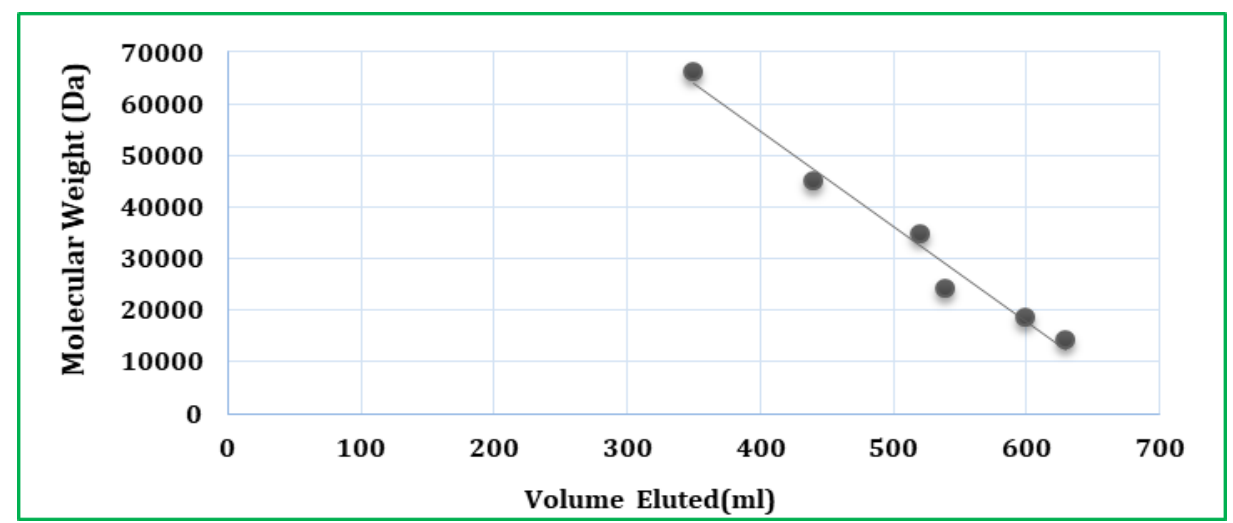

Figure 3 Standard proteins chromatographed on Sepharose CL-6B 200 column for determining the molecular weights of venom proteins/peptides isolated from Polistes flavus. Proteins used were bovine albumin mol. wt 66,000, egg albumin mol. wt. 45,000, pepsin mol. wt. 34,700, trypsinogen mol. wt. 24,000, beta lactoglobulin mol. Wt18,400 and lysozyme mol. wt. 14, 300. Elution volumes of unknown proteins were compared with log values on the X-axis for estimation of molecular weights. 


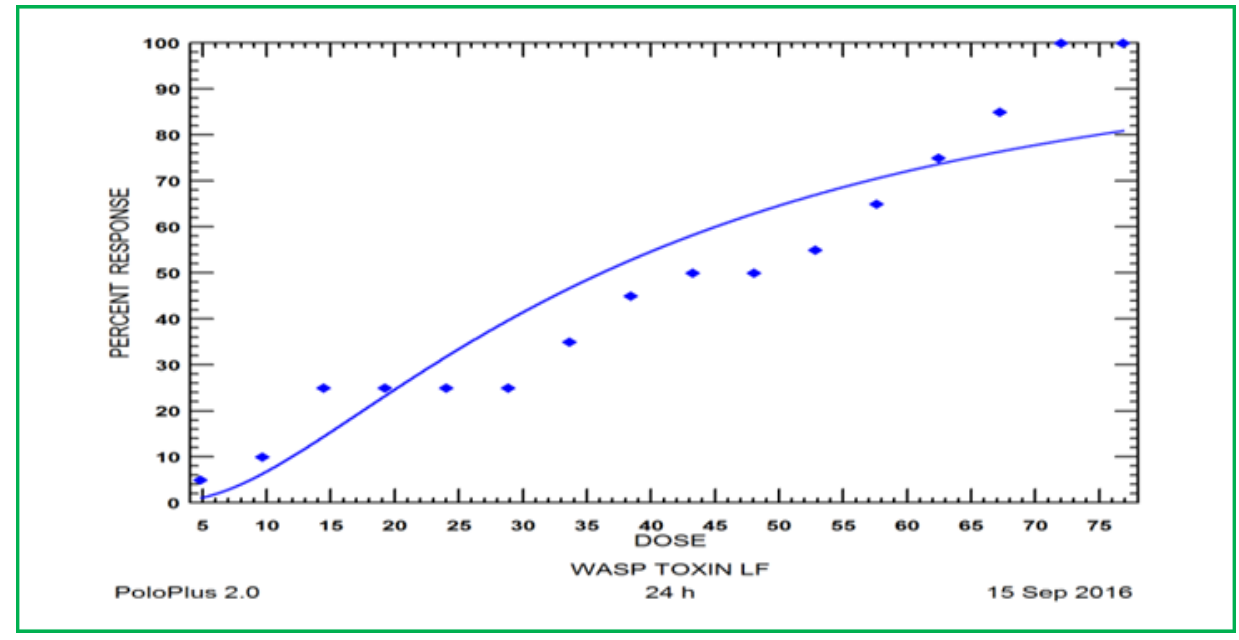

Figure 4Determination of the $\mathrm{LD}_{50}$ of the Polistes flavus venom protein in the albino mice by using mortality which was determined by the Probit method (Fenney, 1971).

The albino mice were injected subcutaneously with the purified venom toxins of different serial concentration and LD 50 was determined at the intervals of the 24 hours. Deformities such as paralysis and neurotoxic effects were also recorded. Similarly fourth stage cockroach nymphs were also injected with serial concentration of the venom toxins to determined $\mathrm{LD}_{50}$. Mortality was determined by using Abbot's formula. The $\mathrm{LD}_{50}$ values were calculated at which half of the test animals were died. The lethal concentration for $40 \%$ and $80 \%$ of the LD50 was determined with the doses-mortality regression line plotted on the log Probit method's (Fenney, 1971) [16]. The confidence limits were calculated at 95\% probability levels.

\subsection{Determination of serum enzymes}

\subsubsection{Determination of (LDH) Lactic dehydrogenase}

Changes in the activity of serum lactic dehydrogenase were measured according to the method of Annon (1984) [17]. For this purpose, $0.05 \mathrm{ml}$ of blood serum was added to $0.5 \mathrm{ml}$ of pyruvate substrate solution was added to it. The mixture was shacked well and incubated at $37^{\circ} \mathrm{C}$ for 45 minutes. Now $0.5 \mathrm{ml}$ of $0.4 \mathrm{~N} \mathrm{NaOH}$ solutions were mixed in test tubes and kept for 30 minutes at room temperature. Optical density was measured at $540 \mathrm{~nm}$ and it was converted to lactic dehydrogenase unit by mean of a special prepared standard curve. Enzymatic activity was expressed as $\mu$ moles of pyruvate reduced/45 minutes/mg protein.

\subsubsection{Determination of serum (AChE) acetyl cholinesterase}

Changes in the activity of the acetyl cholinesterase (AChE) were measured according to the method of Ellman (1961) [18]. For activity testing $0.05 \mathrm{ml}$ of blood serum and $0.10 \mathrm{ml}$ of acetylcholine thio-iodide solution was mixed in a test tube. After adding acetylcholine thio-iodide and added $0.05 \mathrm{ml}$ of DTNB and $1.45 \mathrm{ml}$ of PBS were added to it and shacked well. Changes in optical density were monitored at $412 \mathrm{~nm}$ regularly for 3 minutes at 25으. Enzyme activity was expressed as $\mu$ moles SH hydrolyzed /minute/mg protein.

\subsection{Determination of serum enzymes}

\subsubsection{Determination of (LDH) Lactic dehydrogenase}

Changes in the activity of serum lactic dehydrogenase were measured according to the method of Annon (1984) [17]. For this purpose, $0.05 \mathrm{ml}$ of blood serum was added to $0.5 \mathrm{ml}$ of pyruvate substrate solution was added to it. The mixture was shacked well and incubated at $37^{\circ} \mathrm{C}$ for 45 minutes. Now $0.5 \mathrm{ml}$ of $0.4 \mathrm{~N} \mathrm{NaOH}$ solutions were mixed in test tubes and kept for 30 minutes at room temperature. Optical density was measured at $540 \mathrm{~nm}$ and it was converted to lactic dehydrogenase unit by mean of a special prepared standard curve. Enzymatic activity was expressed as $\mu$ moles of pyruvate reduced/45 minutes/mg protein.

\subsubsection{Determination of serum (AChE) acetyl cholinesterase}

Changes in the activity of the acetyl cholinesterase (AChE) were measured according to the method of Ellman (1961) [18]. For activity testing $0.05 \mathrm{ml}$ of blood serum and $0.10 \mathrm{ml}$ of acetylcholine thio-iodide solution was mixed in a test 
tube. After adding acetylcholine thio-iodide and added $0.05 \mathrm{ml}$ of DTNB and $1.45 \mathrm{ml}$ of PBS were added to it and shacked well. Changes in optical density were monitored at $412 \mathrm{~nm}$ regularly for 3 minutes at $25^{\circ} \mathrm{C}$. Enzyme activity was expressed as $\mu$ moles SH hydrolyzed /minute/mg protein.

\subsection{Determination of enzymes in the tissue of liver and gastrocnemius muscles in albino mice}

\subsubsection{Determination of $(\mathrm{LDH})$ lactic dehydrogenase}

Changes in the activity of serum lactic dehydrogenase were measured according to the method of Annon (1984) [17]. For activity testing $100 \mathrm{mg}$ tissues were homogenized in $1.0 \mathrm{ml}$ of $0.1 \mathrm{M}$ phosphate buffer in ice bath and centrifuged at $10000 \mathrm{x}$ g for 30 minutes in cooling centrifuge. The supernatant was used as enzyme source and the further process was same as previous.

\subsubsection{Determination of (AChE) acetyl cholinesterase}

Changes in the activity of the acetyl cholinesterase (AChE) were measured according to the method of Ellman (1961) [18]. For activity testing $100 \mathrm{mg}$ tissue was homogenized in $50 \mathrm{mM}$ phosphate buffer in ice bath and centrifuged at 1000 $\mathrm{x} g$ for 30 minutes in cooling centrifuge. The supernatant was used as enzyme source and the further process was same as previous.

\subsection{Determination of total protein in serum, liver and gastrocnemius muscles of albino mice}

Estimation of the total protein in the serum, liver, gastrocnemius muscles were carried out by Lowry's method (1915) [19]. In $0.2 \mathrm{ml}$ of blood serum, $0.3 \mathrm{ml}$ of distilled water was added. Now $5.0 \mathrm{ml}$ of freshly prepared alkaline copper solution (Reagent-C/analytical reagent) was added and reaction was allowed for 15 minutes at the room temperature. After 15 minutes $0.5 \mathrm{ml}$ of Folin's reagent (Folin-Ciacalteu) was added in it. Contents were mixed well, after 15 minutes a blue color was developed which was measured at $600 \mathrm{~nm}$. On the other hand $100 \mathrm{ml}$ of tissues i.e., liver and muscles were homogenized in $10 \%$ T.C.A. and centrifuged it $10000 \mathrm{rpm}$ for 10 minutes. The supernatant was used as protein source and estimation of the total protein in liver and muscles were done by same procedure described earlier.

\subsection{In vitro determination of enzymes in the serum of albino mice}

For in vitro study of LDH and AChE enzyme activity blood serum was collected from albino mice. From experimental mice, blood was drawn from the tail region and collected in clean glass test tube. It was allowed to clot in cold. For obtaining serum, clot was carefully separated by using a clean applicator stick around the inner surface of the tube. It was centrifuged immediately in a cooling centrifuge machine at the top speed $15000 \mathrm{rpm}$ for removing any particulate matter from the pellet. Isolated serum was incubated with different concentrations of wasp toxins $(40 \mu \mathrm{g}, 80 \mu \mathrm{g}, 160 \mu \mathrm{g}$ and $320 \mu \mathrm{g}$ ) of purified toxin at $37^{\circ} \mathrm{C}$. Rest of the procedure was followed similar to in vivo experiment.

\section{Results}

Molecular weight of Polistes flavus venom toxins/proteins was determined by Sepharose CL-6B 200 gel column chromatography using standard marker proteins of known molecular weight. The calibration curve indicates that the molecular weight of purified venom proteins ranging from 14.3-63 kDa (Figure 3). The toxicity of the purified wasp venom toxins of the Polistes flavus toxin was determined against albino mice (Mus musculus). The yellow wasp venom proteins obtained from the lyophilization of the two peaks caused toxicity in the albino mice. The $\mathrm{LD}_{50}$ of the yellow wasp Polistes flavus venom protein was found $36.11 \mathrm{mg} /$ kilogram body weight i.e., $0.03611 \mathrm{mg} / \mathrm{gram}$ body weight of albino mice (Figure 4) [20]. 
Table 1 In vivo effects of $40 \%$ of $24-\mathrm{h} \mathrm{LD}_{50}$ of purified venom toxins of Polistes flavus on the activity of lactic dehydrogenase in serum, liver and G. Muscles.

\begin{tabular}{|c|c|c|c|c|c|c|}
\hline \multirow[b]{2}{*}{ Tissues } & \multicolumn{6}{|c|}{ Time in hours } \\
\hline & $\mathrm{O}($ Control) & 2 & 4 & 6 & 8 & 10 \\
\hline Serum & $\begin{array}{l}1.390 \pm 0.7 \\
(100.0)\end{array}$ & $\begin{array}{l}1.410 \pm 0.07 \\
(101.40)\end{array}$ & $\begin{array}{l}1.450 \pm 0.07 \\
(104.30)\end{array}$ & $\begin{array}{l}1.510 \pm 0.07 \\
(108.60)\end{array}$ & $\begin{array}{l}1.570 \pm 0.07 \\
(112.90)\end{array}$ & $\begin{array}{l}1.660 \pm 0.07 \\
(119.40)\end{array}$ \\
\hline Liver & $\begin{array}{l}0.122 \pm 0.08 \\
(100.0)\end{array}$ & $\begin{array}{l}0.151 \pm 0.08 \\
(123.77)\end{array}$ & $\begin{array}{l}0.168 \pm 0.08 \\
(137.70)\end{array}$ & $\begin{array}{l}0.172 \pm 0.08 \\
(140.98)\end{array}$ & $\begin{array}{l}0.186 \pm 0.08 \\
(152.45)\end{array}$ & $\begin{array}{l}0.198 \pm 0.08 \\
(162.29)\end{array}$ \\
\hline G. Muscles & $\begin{array}{l}0.152 \pm 0.08 \\
(100)\end{array}$ & $\begin{array}{l}0.155 \pm 0.08 \\
(101.97)\end{array}$ & $\begin{array}{l}0.159 \pm 0.08 \\
(104.60)\end{array}$ & $\begin{array}{l}0.162 \pm 0.08 \\
(106.57)\end{array}$ & $\begin{array}{l}0.166 \pm 0.08 \\
(109.21)\end{array}$ & $\begin{array}{l}0.172 \pm 0.08 \\
(113.15)\end{array}$ \\
\hline
\end{tabular}

Table 2 In vivo effects of $80 \%$ of 24-h LD50 of purified venom toxins of Polistes flavus on the activity of lactic dehydrogenase in serum, liver and G. Muscles.

\begin{tabular}{|c|c|c|c|c|c|c|}
\hline \multirow{2}{*}{$\mathbf{0}$} & \multicolumn{6}{|c|}{ Time in hours } \\
\hline & 0 (Control) & 2 & 4 & 6 & 8 & 10 \\
\hline Serum & $\begin{array}{l}1.390 \pm 0.79 \\
(100.0)\end{array}$ & $\begin{array}{l}1.421 \pm 0.08 \\
(102.23)\end{array}$ & $\begin{array}{l}1.528 \pm 0.08 \\
(109.92)\end{array}$ & $\begin{array}{l}1.566 \pm 0.08 \\
(112.66)\end{array}$ & $\begin{array}{l}1.678 \pm 0.08 \\
(120.71)\end{array}$ & $\begin{array}{l}1.734 \pm 0.08 \\
(124.74)\end{array}$ \\
\hline Liver & $\begin{array}{l}0.122 \pm 0.016 \\
(100.0)\end{array}$ & $\begin{array}{l}0.168 \pm 0.016 \\
(137.70)\end{array}$ & $\begin{array}{l}0.180 \pm 0.016 \\
(147.54)\end{array}$ & $\begin{array}{l}0.190 \pm 0.016 \\
(155.73)\end{array}$ & $\begin{array}{l}0.201 \pm 0.016 \\
(164.75)\end{array}$ & $\begin{array}{l}0.212 \pm 0.016 \\
(173.77)\end{array}$ \\
\hline G. Muscles & $\begin{array}{l}0.152 \pm 0.08 \\
(100)\end{array}$ & $\begin{array}{l}0.156 \pm 0.08 \\
(102.60)\end{array}$ & $\begin{array}{l}0.161 \pm 0.08 \\
(105.90)\end{array}$ & $\begin{array}{l}0.175 \pm 0.08 \\
(115.10)\end{array}$ & $\begin{array}{l}0.180 \pm 0.08 \\
(118.40)\end{array}$ & $\begin{array}{l}0.198 \pm 0.08 \\
(130.20)\end{array}$ \\
\hline
\end{tabular}

Table 3 In vivo effects of $40 \%$ of 24-h LD50 of purified venom toxins of Polistes flavus on the activity of acetyl cholinesterase in serum, liver and G. Muscles.

\begin{tabular}{|c|c|c|c|c|c|c|}
\hline \multirow[b]{2}{*}{ Tissues } & \multicolumn{6}{|c|}{ Time in hours } \\
\hline & $\mathbf{0}($ Control) & 2 & 4 & 6 & 8 & 10 \\
\hline Serum & $\begin{array}{l}0.664 \pm 0.7 \\
(100.0)\end{array}$ & $\begin{array}{l}0.660 \pm 0.71 \\
(99.39)\end{array}$ & $\begin{array}{l}0.641 \pm 0.70 \\
(96.53)\end{array}$ & $\begin{array}{l}0.625 \pm 0.71 \\
(94.12)\end{array}$ & $\begin{array}{l}0.600 \pm 0.70 \\
(90.36)\end{array}$ & $\begin{array}{l}0.580 \pm 0.71 \\
(87.34)\end{array}$ \\
\hline Liver & $\begin{array}{l}0.634 \pm 0.7 \\
(100.0)\end{array}$ & $\begin{array}{l}0.602 \pm 0.7 \\
(94.95)\end{array}$ & $\begin{array}{l}0.601 \pm 0.7 \\
(94.79)\end{array}$ & $\begin{array}{l}0.585 \pm 0.7 \\
(92.27)\end{array}$ & $\begin{array}{l}0.570 \pm 0.7 \\
(89.90)\end{array}$ & $\begin{array}{l}0.531 \pm 0.7 \\
(83.75)\end{array}$ \\
\hline G. Muscles & $\begin{array}{l}0.524 \pm 0.08 \\
(100)\end{array}$ & $\begin{array}{l}0.505 \pm 0.08 \\
(96.37)\end{array}$ & $\begin{array}{l}0.495 \pm 0.08 \\
(94.46)\end{array}$ & $\begin{array}{l}0.480 \pm 0.08 \\
(91.60)\end{array}$ & $\begin{array}{l}0.458 \pm 0.08 \\
(87.40)\end{array}$ & $\begin{array}{l}0.416 \pm 0.08 \\
(79.38)\end{array}$ \\
\hline
\end{tabular}


Table 4 In vivo effects of $80 \%$ of $24-\mathrm{h} \mathrm{LD}_{50}$ of purified venom toxins of Polistes flavus on the activity of acetyl cholinesterase in serum, liver and G. Muscles.

\begin{tabular}{|c|c|c|c|c|c|c|}
\hline \multirow[b]{2}{*}{ Tissues } & \multicolumn{6}{|c|}{ Time in hours } \\
\hline & $\mathbf{0}$ (Control) & 2 & 4 & 6 & 8 & 10 \\
\hline Serum & $\begin{array}{l}0.664 \pm 0.7 \\
(100.0)\end{array}$ & $\begin{array}{l}0.650 \pm 0.7 \\
(98.00)\end{array}$ & $\begin{array}{l}0.632 \pm 0.7 \\
(95.20)\end{array}$ & $\begin{array}{l}0.617 \pm 0.7 \\
(93.02)\end{array}$ & $\begin{array}{l}0.573 \pm 0.7 \\
(86.42)\end{array}$ & $\begin{array}{l}0.560 \pm 0.7 \\
(84.33)\end{array}$ \\
\hline Liver & $\begin{array}{l}0.634 \pm 0.07 \\
(100.0)\end{array}$ & $\begin{array}{l}0.621 \pm 0.07 \\
(97.94)\end{array}$ & $\begin{array}{l}0.592 \pm 0.07 \\
(93.37)\end{array}$ & $\begin{array}{l}0.567 \pm 0.7 \\
(89.43)\end{array}$ & $\begin{array}{l}0.532 \pm 0.7 \\
(83.91)\end{array}$ & $\begin{array}{l}0.501 \pm 0.7 \\
(79.02)\end{array}$ \\
\hline G. Muscles & $\begin{array}{l}0.524 \pm 0.08 \\
(100)\end{array}$ & $\begin{array}{l}0.500 \pm 0.08 \\
(95.41)\end{array}$ & $\begin{array}{l}0.491 \pm 0.08 \\
(93.70)\end{array}$ & $\begin{array}{l}0.472 \pm 0.08 \\
(90.07)\end{array}$ & $\begin{array}{l}0.448 \pm 0.08 \\
(85.49)\end{array}$ & $\begin{array}{l}0.405 \pm 0.08 \\
(77.29)\end{array}$ \\
\hline
\end{tabular}

Table 5 In vitro effects of the purified wasp venom toxins of Polistes flavus on lactic dehydrogenase (LDH) and acetyl cholinesterase (AChE) on blood serum of albino mice.

\begin{tabular}{llllll}
\hline \multirow{2}{*}{ Enzymes } & \multicolumn{2}{l}{ Doses of venom toxin in $\boldsymbol{\mu g}$} \\
$\mathbf{0} \boldsymbol{\mu g}$ (control) & $\mathbf{4 0} \boldsymbol{\mu g}$ & $\mathbf{8 0} \boldsymbol{\mu g}$ & $\mathbf{1 6 0} \boldsymbol{\mu g}$ & $\mathbf{3 2 0} \boldsymbol{\mu g}$ \\
\hline \multirow{2}{*}{$\mathrm{LDH}$} & $1.393 \pm 0.81$ & $1.348 \pm 0.81$ & $1.302 \pm 0.81$ & $1.276 \pm 0.81$ & $1.090 \pm 0.81$ \\
& $(100)$ & $(96.76)$ & $(93.46)$ & $(91.60)$ & $(78.24)$ \\
\multirow{2}{*}{$\mathrm{AChE}$} & $0.523 \pm 0.81$ & $0.136 \pm 0.81$ & $0.136 \pm 0.81$ & $0.141 \pm 0.81$ & $0.137 \pm 0.81$ \\
& $(100)$ & $(26.11)$ & $(26.11)$ & $(26.95)$ & $(26.19)$ \\
\hline
\end{tabular}

Values are mean \pm SE of three replicates;Values in parentheses indicates percentage level with control taken as $100 \%$; ${ }^{*}$ Significant (p<0.05, Student $t-$ test); *Significant ( $<<0.05$, F-test).Blood serum, liver and G. muscles was the enzyme and protein source. G. muscles= Gastrocnemius muscles.Lactic dehydrogenase (LDH): $\mu$ moles of pyruvate reduced/45 minutes/mg protein; Acetyl cholinesterase (AChE): $\mu$ moles 'SH' hydrolyzed/minute/mg protein.

In this section toxic effect of the purified venom toxins of Polistes flavus were observed in albino mice on serum enzyme activity of lactic dehydrogenase and acetyl cholinesterase. The albino mice were treated with $40 \%$ and $80 \%$ of $24-\mathrm{h} \mathrm{LD}_{50}$ of purified wasp toxins and lactic dehydrogenase (LDH) and acetyl cholinesterase (AChE) enzymes activity were measured after 2, 4, 6, 8 and 10 hours of treatment. Wasp venom caused significant increase in lactic dehydrogenase activity in serum, liver and muscles of albino mice, while the activity of acetyl cholinesterase was inhibited in treated mice in comparison to control mice.

The activity of lactic dehydrogenase in the serum of albino mice increased $119.40 \%$ and $124.74 \%$ of the control at 10 hours of treatment with $40 \%$ and $80 \%$ of 24 -h LD 50 of wasp venom. Maximum increase in lactic dehydrogenase activity was observed the liver after 10 hours of treatment of wasp venom. In liver the maximum increase in lactic dehydrogenase activity was $162.29 \%$ and $173.77 \%$ of the control at $40 \%$ and $80 \%$ of 24 -h LD 50 respectively. On the other hand the activity of the LDH was increased $113.15 \%$ and $130.20 \%$ of the control at $40 \%$ and $80 \%$ of 24 -h LD 50 respectively in gastrocnemius muscles of albino mice (Table 1 \& 2; Figure 5 \& 6).

The activity of the AChE was decreased s up to $87.34 \%$ and $84.33 \%$ of the control at $40 \%$ and $80 \%$ of $24-\mathrm{h}$ LD50 respectively after 10 hours treatment in albino mice when treated with purified wasp toxins. The acetyl cholinesterase activity in the liver of albino mice was decreased s up to $83.75 \%$ and $79.02 \%$ of the control at $40 \%$ and $80 \%$ of 24 -h $\mathrm{LD}_{50}$ after 10 hours of the treatment respectively. On the other hand in gastrocemius muscles the activity of AChE were found $79.38 \%$ and $77.29 \%$ of the control at $40 \%$ and $80 \%$ of $24-\mathrm{h} \mathrm{LD}_{50}$ respectively after 10 hours treatment with wasp venom (Table 3 \& 4; Figure 7 \& 8).

For in vitro study, four concentrations i.e., $40 \mu \mathrm{g}, 80 \mu \mathrm{g}, 160 \mu \mathrm{g}$ and $320 \mu \mathrm{g}$ of purified venom toxins were used to study the in vitro effects on enzymes activity of lactic dehydrogenase and acetyl cholinesterase. Pre-incubation of purified venom of wasp causes a significant $(\mathrm{p}<0.05)$ dose dependent effects and activity of LDH decreases 96.76\%, 93.46\%, $91.60 \%$ and $78.24 \%$ of the control $(100 \%)$ at $40 \mu \mathrm{g}, 80 \mu \mathrm{g}, 160 \mu \mathrm{g}$ and $320 \mu \mathrm{g}$ of wasp toxin (Table and figure) on the other hand, the activity of AChE was decreases $26.11 \%$ of the control at $40 \mu \mathrm{g}$ but not altered and remain constant at the doses of $40 \mu \mathrm{g}, 80 \mu \mathrm{g}, 160 \mu \mathrm{g}$ and $320 \mu \mathrm{g}$ of wasp toxin respectively(Table 5 and Figure 9). 


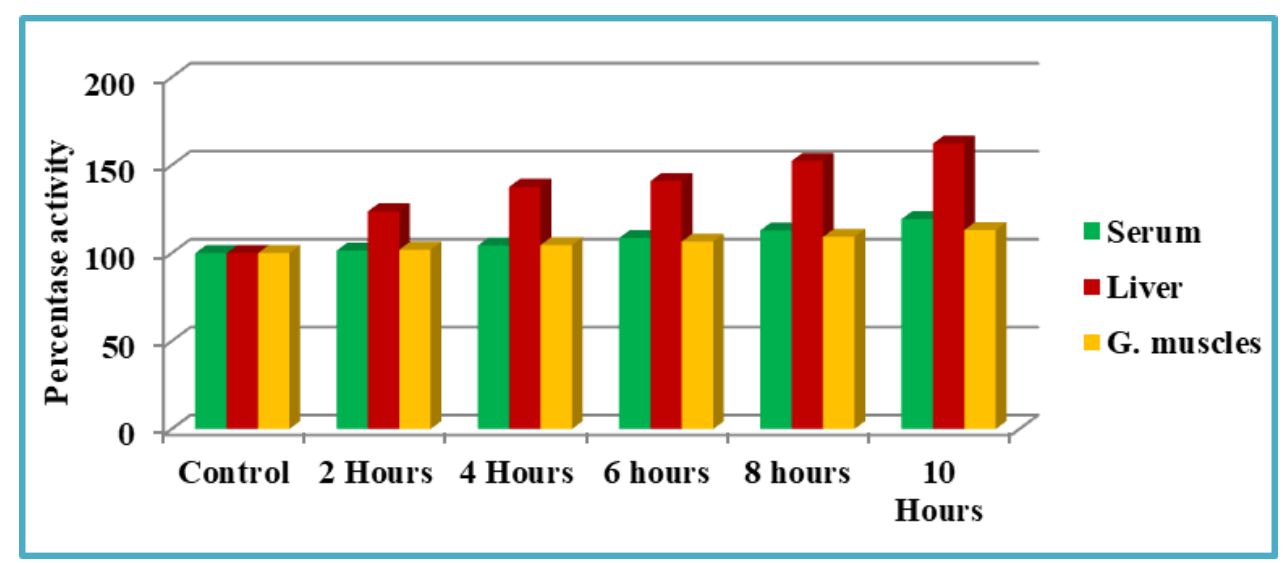

Figure 5 Lactic dehydrogenase activity in serum, liver and Gastrocnemius muscles in albino mice treated with 24hours LD50 40\%.

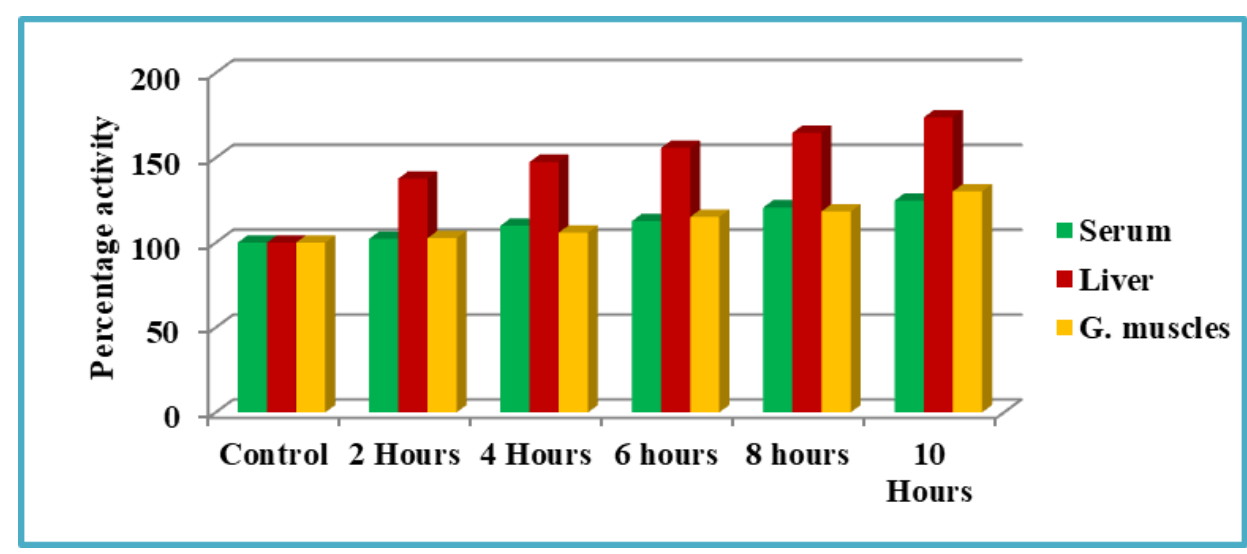

Figure 6 Lactic dehydrogenase activity in serum, liver and Gastrocnemius muscles in albino mice treated with 24hours LD50 80\%.

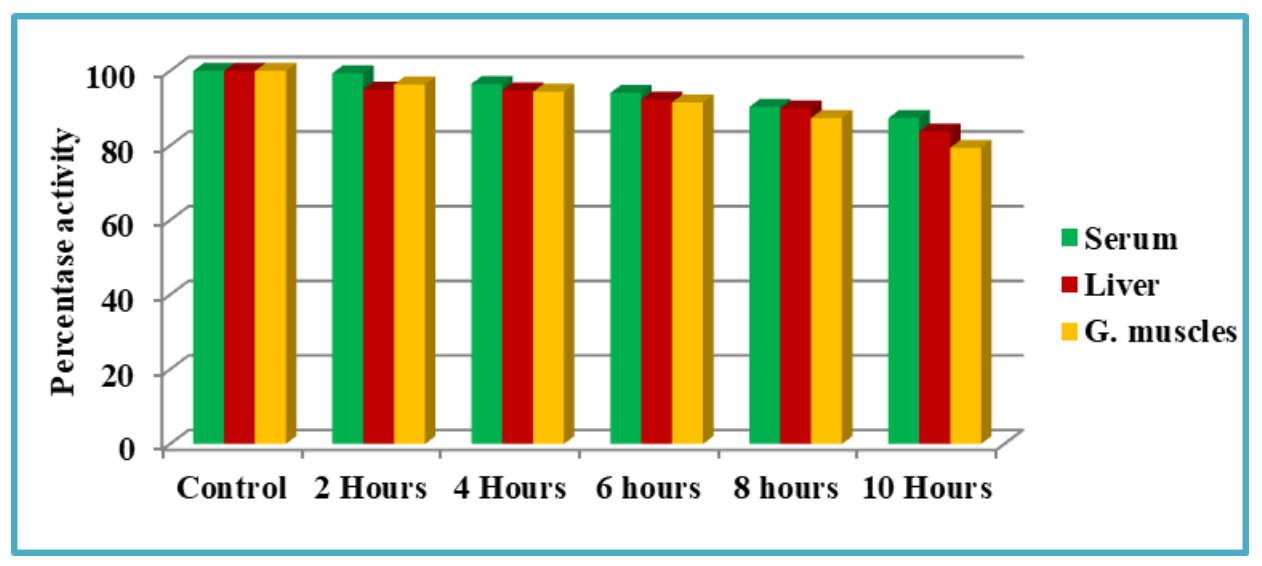

Figure 7 Acetyl cholinesterase activity in serum, liver and Gastrocnemius muscles in albino mice treated with 24hours LD50 40\%. 


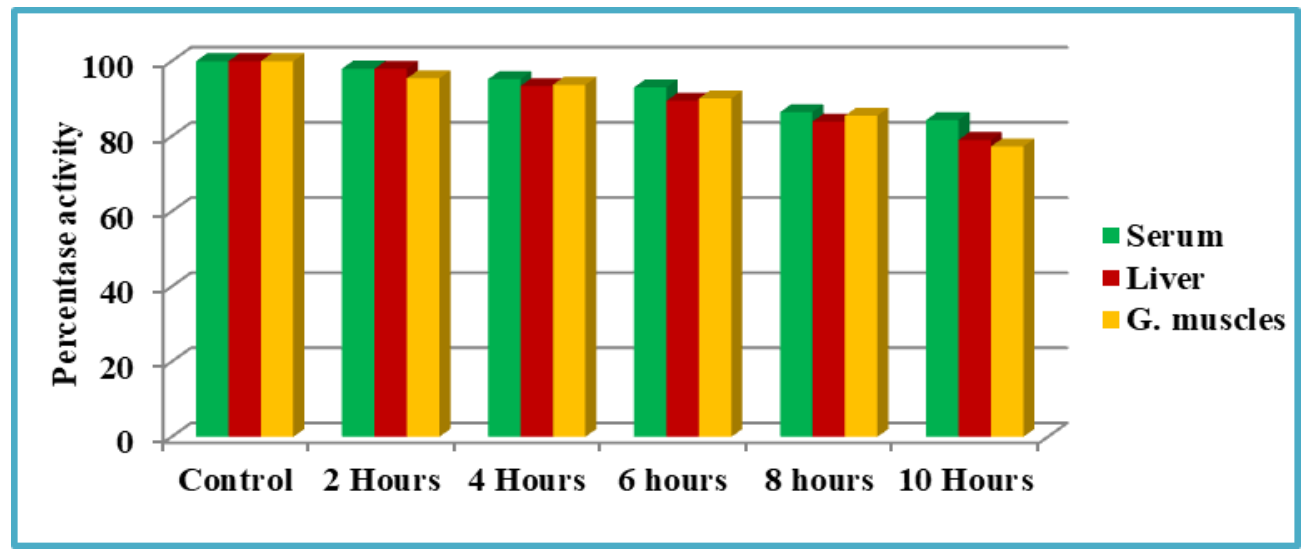

Figure 8 Acetyl cholinesterase activity in serum, liver and Gastrocnemius muscles in albino mice treated with 24hours LD5080\%.

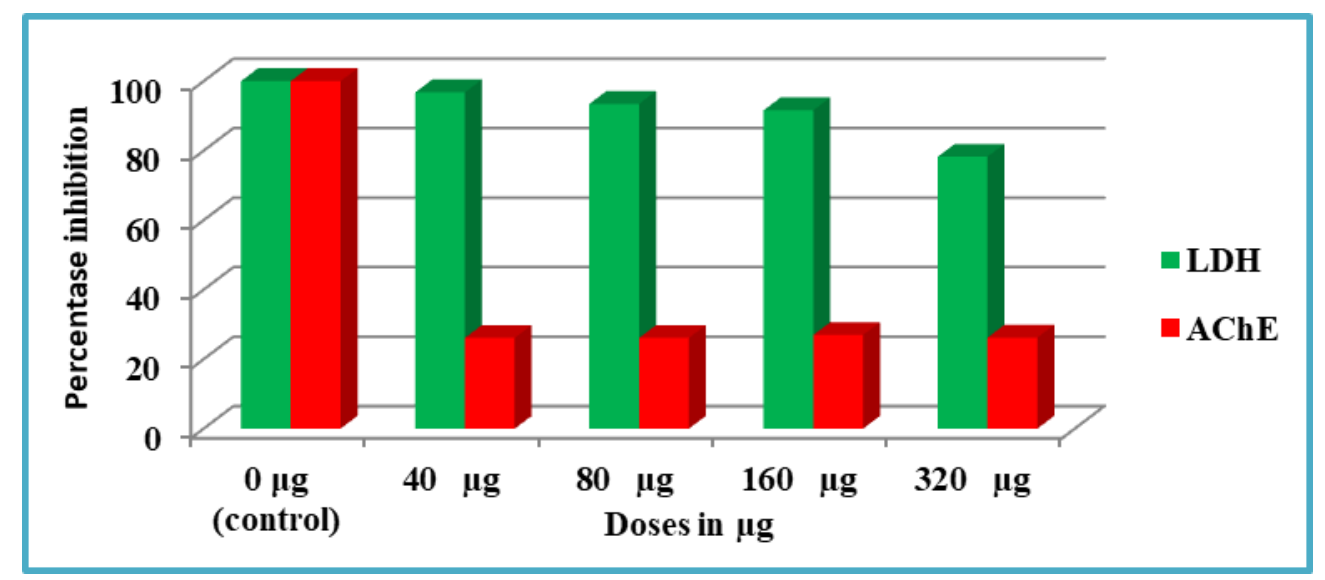

Figure 9 In vitro inhibition of the LDH and AChE enzyme activity by the wasp venom toxin at different doses.

\section{Discussion}

In the present study wasp Polistes flavus venom toxins were purified on Sepharose CL-6B 200 gel filtration column chromatography. Venom toxins have shown presence of low molecular weight proteins. These venom toxins displayed severe physiological effects such as hemolytic, neurotoxic, cytotoxic activities and paralytic effects in albino mice and also caused irreversible flaccid paralysis and effect neuromuscular function in animals [21]. The activity of certain metabolic enzymes was also found to be altered after injection of sub lethal dose of purified Polistes flavus venom toxins to the albino mice. A significant elevation was observed in serum, liver and gastrocnemius muscles lactic dehydrogenase activity, while a significant $(\mathrm{p}<0.05)$ reduction was observed in acetyl cholinesterase activity in albino mice. However, it is well known that liver synthesize metabolic enzymes and stored them for catabolic activity. However, wasp venom toxins disintegrate liver cells and cause liver intoxication. The activity of some enzymes involved in hepatic function was measured and envenomation with Hornet's (Vespa orientalis) venom induces enzymatic changes in the liver after prolonged, repeated exposures. Wasp toxins cause hepatic damage in rats, in vivo that hinder detoxification process in hepatocytes [22].

Lactic dehydrogenase is an intracellular enzyme found at high level in tissues, particularly, in liver, heart, skeletal muscle, kidney, brain and lungs. Lactic dehydrogenase is cellular metabolic enzyme with no evident function in vertebrate plasma. It also occurs in small concentrations in plasma, which may be delivered from the regular physiological shedding of cells [23]. Its activity was found to be increased up to $124.74 \%$ in serum (Table 2, Figure 6), while in liver and gastrocnemius muscles the activity of the lactic dehydrogenase was increased up to $173.77 \%$ and $130.20 \%$ of the control at 10 hour respectively (Table 2; Figure 6). Increase in the level of LDH shows, liver damage, massive disintegration of cells and leakage of the enzyme in to the circulation [24]. The genotoxic and mutagenic activity of the venom of P. paulista was due to the action of phospholipase, mastoparans and hyaluronidase, which are able to disrupt the cell membrane. LDH thereby interact with the genetic material of the cells or even facilitate the entrance of other compounds of the venom which can act on the DNA molecules. This genotoxic and mutagenic action of the venom 
may be due presence of substances which may trigger inflammatory process and, consequently, generate oxygen reactive species that can interact with the DNA of the exposed cells [3].

Therefore, any detectable increase in their activity in plasma can be used as a reliable indicator of changes in metabolic functions and structural damage in tissues [24]. Polistes flavus venom caused massive cellular toxicity in liver cells and caused significant alterations in cell permeability of myocardial, liver and smooth muscle cells, which may facilitate the release of certain metabolic enzymes out of the cells mainly in to the circulation [25]. Besides LDH, AST or ALT levels are valuable and aid primarily in the diagnosis of liver disease. Although not specific for liver disease, it can be used in combination with other enzymes to monitor the course of various liver disorders.

High LDH level shows stress and hypertension, it increases the rate of oxidation in animals. Therefore, elevation in LDH level increases the glucose catabolism for energy production especially in anaerobic condition. Besides this, increased level of LDH in muscle and liver cells shows insufficient oxygen supply. It is well known that pyruvic acid is the main end product of glycolysis in those tissues, which supply oxygen in abundance, but in those tissues where oxygen supply is insufficient or in anaerobic state. Example skeletal muscles lactic acid form the usual end product of glycolysis [26]. In such cases pyruvic acid is reduced to lactic acid under the influence of lactic dehydrogenase. ${ }^{* * * * *}$

On the other hand activity of serum acetyl cholinesterase was found to be reduced up to $84.33 \%$ at 10 hour of the venom injection in comparison to control (Table 4; Figure 8). The acetyl cholinesterase activity in liver and gastrocnemius muscles was also found to be decreased significantly up to $79.02 \%$ and $77.29 \%$ at 10 hour in comparison to control (Table 4; Figure 8). This inhibition of acetyl cholinesterase activity causes accumulation of acetylcholine molecules at the synaptic junctions. The accumulation of acetylcholine may lead to prolonged activation of acetylcholine receptors and a permanent stimulation of nerves and muscle cells resulting in muscular paralysis and finally death of animal [27].

Thr6-bradykinin is a peptide found in the venom of social and solitary wasp Polybia occidentalis olivier (Vespidae). It affects the central nervous system (CNS), but do not show any effect on mammalian cholinergic transmission. Nevertheless, this selectivity for the insect CNS, combined with its irreversible mode of action may be relevant to the discovery of new sources of insecticides. It implicates role of kinins in the mammalian CNS [28]. The venom of Nemopilema nomurai jellyfish induces a significant impact on the economy by producing more than $80 \%$ of the globally produced raw silk. The enzymes Acetyl cholinesterase (AChEs) is very sensitive to fasciculin inhibition. It is a noncompetitive inhibitor of the hydrolysis of choline and neutral esters by very sensitive AChEs. Fasciculin still behaves as a non-competitive inhibitor with choline esters [29]. In contrast, hydrolysis of phenylacetate was unaffected or slightly increased with BChEs and a partial competitive inhibition was observed with cobra venom and chicken enzymes. Butyrylcholinesterases (BChEs) enzymes lack these amino acids like or one or two of them like cobra venom, insect and chicken AChEs are 1000 to 1,000,000 times less sensitive[30].

In the present study the Polistes flavus venom protein induce the significance changes in the activity and Lactic dehydrogenases and Acetyl cholinesterase activity in the serum, liver and gastrocnemius muscles of the albino mice in vivo condition. As in vitro venom toxin of the Polistes flavus directly effects the Lactic dehydrogenases activity but don not directly affect the acetyl cholinesterase in the serum of the albino mice. It indicates that venom toxin of Polistes flavus causes biochemical changes in the serum and muscular tissues in the body of the albino mice and these changes creates the secondary metabolites in the serum of the mice. But these secondary metabolites effect the acetyl cholinesterase activity in the body of the albino mice (Table 5; Figure 9). However, in vitro condition the venom toxin not affects directly induces the activity of the serum acetyl cholinesterase. This explanation emphasize that Polistes flavus venom contains some neurotoxin that actively affects nerve transmission activity in insects and does inhibition of enzymatic reactions involved in it.

\section{Conclusion}

Present research work on enzymatic activity of wasp venom toxins would be used as a bio-marker for determination of wasp venom toxicity. This study will assist in wasp venom therapeutics and clinical treatment to restore tissue damage, healing of necrosis of hepatic cells and normal function of enzymes in the blood circulation.

\section{Compliance with ethical standards}

\section{Acknowledgments}

Authors are thankful HOD, Department of Zoology for research facilities. 


\section{Disclosure of conflict of interest}

The authors declare no competing financial interests.

\section{Statement of ethical approval}

All animal subjects were local breed of mice which were used for all experimental purposes. No animal species has been used for experiments which are under animal prohibition act. The albino mice were reared in the laboratory by providing proper diet and care. All animals were provided humanitarian concern during their culture and use for experiments.

\section{References}

[1] Hardy MC, Cochrane J and Allavena RE. (2014). Venomous and poisonous Australian animals of veterinary importance: A Rich Source of Novel Therapeutics. Bio. Med. Res. Int. 671041.

[2] Schmidt J0. (2014). Evolutionary responses of solitary and social Hymenoptera to predation by primates and over whelmingly powerful vertebrate predators. J. Hum. Evol, 71, 12-9.

[3] Hoshina MM, Santos LD, Palma MS and Marin-Morales MA. (2013). Cytotoxic, genotoxic/antigenotoxic and mutagenic/antimutagenic effects of the venom of the wasp Polybia paulista. Toxicon. 72, 64-70.

[4] Norager NG, Poulsen MH, Jensen AG, Jeppesen NS, Kristensen AS and Strømgaard K. (2014). Structure-activity relationship studies of $\mathrm{N}$-methylated and $\mathrm{N}$-hydroxylated spider polyamine toxins as inhibitors of ionotropic glutamate receptors, J Med Chem, 57(11), 4940-9.

[5] Xie C, Xu S, Ding F, Xie M, Lv J and Yao J. (2013). Clinical features of severe wasp sting patients with dominantly toxic reaction: analysis of 1091 cases, 8(12), e83164.

[6] Nordman JC, Phillips WS, Kodama N, Clark SG, Del-Negro CA and Kabbani N. (2014). Axon targeting of the alpha 7 nicotinic receptor in developing hippocampal neurons by Gprin1 regulates growth. J. Neurochem, 129(4), 64962.

[7] King GF and Hardy MC. (2013). Spider-venom peptides: structure, pharmacology, and potential for control of insect pest, Annu. Rev. Entomol, 58, 475-96.

[8] Freeman TM. (2004). Hypersensitivity to hymenoptera stings, New England Journal of Medicine, 351, 19.

[9] Blank S, Seismann H, McIntyre M, Ollert M, Wolf S, Bantleon FI and Spillner E. (2013). Vitellogenins are new high molecular weight components and allergens (Api m 12 and Ves v 6) of Apis mellifera and Vespula vulgaris venom, 8(4), e62009.

[10] Karst H, Piek T, Van Marle J, Lind A and Van Weeren-Kramer J. (1991). Structure-activity relationship of philanthotoxins--I. Pre- and postsynaptic inhibition of the locust neuromuscular transmission, Comp BiochemPhysiol C, 98(2-3), 471-7.

[11] Moore EL, Haspel G, Libersat F and Adams ME. (2006). Parasitoid wasp sting: a cocktail of GABA, taurine, and beta-alanine opens chloride channels for central synaptic block and transient paralysis of a cockroach host. J. Neurobiol, 66(8), 811-20.

[12] Oslen CA, Meller IR, Wellendorph P and Usherwood PN. Witt M, Franzy H and Jaroszewki JW. (2006).Tuning wasp toxin structure for nicotinic receptor antagonism: cyclohexylalamine-containing analogues as potent and voltage-dependent blockers, Chem. Med. Chem, 1(3), 303-305.

[13] Colovic MB, Krstic DZ, Lazarević-Pašti TD, Bondžić AM and Vasić VM.(2013). Acetyl cholinesterase inhibitors: pharmacology and toxicology.CurrNeuropharmacol. 11(3), 315-35.

[14] Piek T, Hue B, Mantel P, Nakajima T, Pelhate M and Yasuhara T. (1990). Threonine6-bradykinin in the venom of the wasp Colpainterrupta (F.) pre-synaptically blocks nicotinic synaptic transmission in the insect CNS. Comp Biochem. Physiol. C, 96(1), 157-62.

[15] Krishna KP and Ravi KU. (2018). Wasp venom toxin induced hematological changes in albino mice. World Journal of Pharmaceutical Research, 7, 13.

[16] Fenney DJ. (1971). Probit analysis, 3rd ed. Cambridge University, London, UK, 333. 
[17] Annon TM. (1984). Sigma diagnostic: Lactate dehydrogenase (Quantitative, Colorimetric determination in serum, urine and cerebrospinal fluid) at 400-500 nm. Procedure No. 500.

[18] Ellman GL, Courtney KD, Andres V and Featherstone RM. (1961). A new and rapid colorimetric determination of acetyl cholinesterase activity. Biochem. Pharmacol, 7, 88-95.

[19] Lowry OH, Rosenbrough NJ, Farr AL and Randall RJ. (1951). Protein measurement with phenol reagent. J. Biol. Chem, 193, 265- 275.

[20] Krishna KP and Ravi KU. (2019). In vivo effects of the purified venom of Polistes flavus on blood bio-molecules in albino mice. International Journal of Research and Analytical Reviews. 6(2), 132-147.

[21] Banks BEC and Shipolini RA. (1986). Chemistry and pharmacology of honey-bee venom. In: Piek T., editor. Venoms of the Hymenoptera: Biochemical, Pharmacological and Behavioral Aspects. Academic Press; London, UK, 330-416.

[22] Krajnovic-Ozretic M and Ozretic B. (1987). Estimation of the enzymes LDH, GOT, and GPT in plasma of grey mullet, Mugila uratus and their significance in liver intoxication, Disease of Aquatic Organisms, 3, 187-193.

[23] Schmidt E and Schmidt FW. (1974). The importance of enzymatic analysis in medicine. In: methods of enzymatic analysis, Vol. I (Bergmeyer, H. U. ed). Acadmic Press, New York, 6-14.

[24] Bouck GR. (1966). Changes in blood and muscles composition of rock bass (Ambloplites rupestris) as physiological criteria of stressful conditions. Ph. D. dissertation, Michigan State University, East Landing, Michigan, USA.

[25] Murthy RK and Haghanazari L. (1999). The blood level of glucagons, cartisol and insulin following the injection of venom by the scorpion (Mesobuthus tumulus concanesis) in dogs. J. venom. Anim. Toxins, 5, 48-53.

[26] Fischer EH, Heilmeyer LMG and Hashcke RH. (1971). Phosphorylase and the control of glycogen degradation. Curr. Trop. Cell. Regul, 4(211), 707-710.

[27] Neuman MG, Eshchar J, Cotariu D, Ishay JS and Bar-Nea L. (1983). Hepatotoxicity of hornet's venom sac extract, after repeated in vivo and in vitro envenomation. Acta Pharmacol Toxicol (Copenh).53(4), 314-9.

[28] Mortari MR, Cunha AO, Carolino RO, Silva JC, Lopes NP and Santos WF. (2016). Evaluation of Thr6-bradykinin purified from Polybia occidentalis wasp venom in the choline uptake of mammal cortices. Pharm Biol. 54(12), 3169-3171.

[29] Yu H, Li R, Chen X, Yue Y, Xing R, Liu S and Li P. (2015). Effect of Venom from the Jellyfish Nemopilema nomurai on the Silkworm Bombyx mori L. Toxins (Basel). 24, 7(10), 3876-86.

[30] Durán R, Cerveñansky C and Karlsson E. (1996). Effect of fasciculin on hydrolysis of neutral and choline esters by butyrylcholinesterase, cobra venom and chicken acetylcholinesterases. Toxicon. 34(8), 959-63.

\section{How to cite this article}

Prajapati KK and Upadhyay RK. (2020). Effects of paper wasp (Polistes flavus) venom toxins on lactic dehydrogenase (LDH) and acetyl cholinesterase (AChE) activity in blood serum, liver and muscles of albino mice. World Journal of Advanced Research and Reviews, 6(1), 173-184. 